\title{
Poultry litter and cotton seed meal as supplements for cattle grazing dry season pasture in Zimbabwe
}

\author{
B. Manyuchi, T. Smith and S. Mikayiri \\ Grasslands Research Station, PB 3701, Marondera, Zimbabwe
}

\section{Introduction}

Feeding supplementary nitrogen is necessary to reduce live-weight loss in ruminants grazing dry season natural pasture (veld) in the tropics. The current study compared air-dried $(910 \mathrm{~g}$ dry matter (DM) per kg) deep litter poultry manure (DPM) with cotton seed meal (CSM) as a supplement for cattle and sheep.

\section{Material and methods}

In experiment 1, 50 weaner steers of the Mashona breed were divided into five groups of 10 each and given either no supplement (control) or a daily supplement of $32 \mathrm{~g}$ nitrogen $(\mathrm{N})$ per animal from CSM, $D P M$ or CSM + DPM in the ratio (based on $N$ contribution) of $2: 1$ (LoDPM) or $1: 2$ (HiDPM), while grazing veld during the dry season from June to October. Another group of 10 steers was slaughtered at the outset to estimate initial carcass weight. Carcass composition was estimated from a minced sample of three-rib joint (ribs 9, 10 and 11).

In experiment 2,16 Merino lambs weighing $35.0( \pm 1.5)$ $\mathrm{kg}$ were given veld hay $(\mathrm{N}=4 \mathrm{~g} / \mathrm{kg} D M)$ milled through a 14-mm screen ad libitum either alone (control) or with a daily supplement of $8 \mathrm{~g} \mathrm{~N}$ from CSM, DPM or CSM + DPM $(1: 1)$ with four replicates per treatment. Intake, digestibility and $\mathrm{N}$ retention were measured after a 3-weeks adaptation period.

In experiment 3 rumen degradability of CSM and DPM were determined using the nylon-bag technique, in steers fitted with rumen cannulae, given veld hay plus a daily supplement of CSM or DPM ( $36 \mathrm{~g} \mathrm{~N}$ per animal). CSM and DPM were incubated in the rumen of each steer receiving the respective supplement. Rumen $\mathrm{pH}$ and ammonia were also measured $3 \mathrm{~h}$ after feeding supplements.

\section{Results}

The N contents of DPM and CSM were 24 and $64 \mathrm{~g} / \mathrm{kg}$ DM respectively. In experiment 1 , the daily allowances of supplements were $0.50,0.79,1.08$ and $1.37 \mathrm{~kg}$ for CSM, LoDPM, HiDPM and DPM respectively. All supplements prevented live-weight loss and reduced or eliminated carcass weight loss $(P<0.05$; Table 1$)$. Fat and protein contents of the three-rib joint were also higher in animals given supplements. In experiment 2 , all the supplements increased intake of veld hay, total food intake and $N$ retention $(P<0.05)$ without altering digestibility of the diets (Table 2). Rumen degradability studies showed that DPM had a higher readily soluble component and extent of degradation of $\mathrm{N}$ compared with CSM (Table 3). Rumen ammonia $(\mathrm{mg} / \mathrm{l})$ was 121 and 212 and $\mathrm{pH}$ was 6.9 and 6.8 in the cattle given CSM and DPM supplements respectively

\section{Discussion}

DPM on its own was inferior to CSM, but was effective in preventing live-weight loss in steers and increasing $N$ retention and intake of veld hay by sheep. Supplements of DPM + CSM were as effective as CSM on its own, probably reflecting the effect of combining supplements of different degradability characteristics. DPM can thus be used as a cheap source of rumen degradable $N$. The suggestion of a synergistic effect when DPM and CSM were given together may have reflected the relative contributions of rumen degradable $\mathbf{N}$ and undegradable dietary protein by the two supplements. 
Table 1 Live weight and carcass weight measurements in steers given no supplement (control) or a daily supplement of $32 \mathrm{~g}$ nitrogen from cotton seed ineal (CSM), poultry manure (DPM) or DPM +CSM in the ratio $1: 2$ (LoDPM) or $2: 1$ (HiDPM) while grazing veld during the dry season.

\begin{tabular}{|c|c|c|c|c|c|c|}
\hline \multirow[b]{2}{*}{. } & \multicolumn{6}{|c|}{ Supplement } \\
\hline & Control & CSM & LoDPM & HiDPM & DIM & s.e.d. \\
\hline \multicolumn{7}{|l|}{ Live weight (kg) } \\
\hline Initial & 177 & 177 & 176 & 176 & 174 & 1.2 \\
\hline Final & $161^{\mathrm{a}}$ & $191^{b}$ & $199^{b}$ & $199 \mathrm{~b}$ & $182^{\mathrm{h}}$ & $7 \cdot 4$ \\
\hline Live-weight change (g/day) & $-124^{a}$ & $108^{\mathrm{bc}}$ & $184^{c}$ & $144^{\mathrm{bc}}$ & $64^{b}$ & $57 \cdot 4$ \\
\hline \multicolumn{7}{|l|}{ Carcass weight $(\mathrm{kg})$} \\
\hline Intial & $84 \cdot 6$ & 84.9 & $84 \cdot 3$ & $84 \cdot 0$ & 82.9 & 0.71 \\
\hline Final & $68 \cdot 6^{a}$ & $84 \cdot 8^{\text {bc }}$ & $87.9 \mathrm{c}$ & $83 \cdot 0^{\text {the }}$ & $79.5^{b}$ & $3 \cdot 30$ \\
\hline Carcass-weight change ( $\mathrm{g} /$ day) & $-128^{a}$ & $-0.8^{c}$ & $29.0^{d}$ & $-5 \cdot 0^{*}$ & $-27 \cdot 0^{b}$ & $2 \cdot 57$ \\
\hline \multicolumn{7}{|l|}{ Composition of rib joint $(\mathrm{g})$} \\
\hline Fat & $39 \cdot 6^{\mathrm{a}}$ & $72 \cdot 8^{b}$ & $76 \cdot 8^{b}$ & $67 \cdot 2^{b}$ & $65 \cdot 0^{b}$ & $7 \cdot 8$ \\
\hline Protein & $226 \cdot 8^{a}$ & $273.0^{c}$ & $312 \cdot 0^{d}$ & $270.2^{\text {bc }}$ & $248 \cdot 3^{a b}$ & 10.9 \\
\hline
\end{tabular}

$a, b, c, d$ Means in the same row with different superscripts are significantly different $(P<0.05)$.

Table 2 Intake, digestibility and nitrogen retention measured in lambs given veld hay alone or with a supplement of $8 \mathrm{~g}$ nitrogen from cotton seed meal (CSM), poultry manure (DPM) or DPM + CSM $(1: 1)$

\begin{tabular}{|c|c|c|c|c|c|}
\hline & \multicolumn{5}{|c|}{ Supplement } \\
\hline & Control & CSM & $\mathrm{CSM}+\mathrm{DPM}$ & DPM & s.e.d. \\
\hline \multicolumn{6}{|l|}{ Daily intake (g) } \\
\hline Veld hay & $542^{a}$ & $666^{b}$ & $646^{b}$ & $679^{b}$ & $20 \cdot 4$ \\
\hline Total diet & $542^{a}$ & $786^{b}$ & $846^{c}$ & 959d & 25.8 \\
\hline \multicolumn{6}{|l|}{ Apparent digestibility } \\
\hline Dry matter & 0.47 & 0.52 & 0.50 & 0.47 & 0.019 \\
\hline Organic matter & 0.48 & 0.53 & 0.50 & 0.53 & 0.024 \\
\hline Nitrogen retention ( $\mathrm{g} /$ day) & $-0.5^{a}$ & $4.0^{c}$ & $3 \cdot 6^{c}$ & $1.8^{b}$ & 0.19 \\
\hline
\end{tabular}

$\mathrm{a}, \mathrm{b}, \mathrm{d}, \mathrm{d}$ Means in the same row with different superscripts are significantly different $(P<0.05)$.

Table 3 Nitrogen degradability (\%) of cotton seed meal (CSM) and poultry manure (DPM) incubated in nylon bags in the rumen of steers given veld hay and the respective supplement

\begin{tabular}{|c|c|c|c|c|c|c|c|c|}
\hline & \multicolumn{5}{|c|}{ Time (h) } & \multicolumn{3}{|c|}{ Constantst } \\
\hline & 3 & 6 & 12 & 24 & 48 & $a$ & $\boldsymbol{b}$ & $c$ \\
\hline $\begin{array}{l}\text { CSM } \\
\text { DPM } \\
\text { s.e.d. }\end{array}$ & $\begin{array}{l}23 \cdot 6 \\
74 \cdot 3\end{array}$ & $\begin{array}{l}30.7 \\
75.9\end{array}$ & $\begin{array}{l}44 \cdot 1 \\
79 \cdot 0\end{array}$ & $\begin{array}{l}55.5 \\
84.8\end{array}$ & $\begin{array}{l}57.5 \\
88.4\end{array}$ & $\begin{array}{r}18 \cdot 0 \\
70.9^{b} \\
3.50\end{array}$ & $\begin{array}{r}47 \cdot 1^{b} \\
18 \cdot 3^{a} \\
5 \cdot 60\end{array}$ & $\begin{array}{l}0.033^{\mathrm{a}} \\
0.056^{\mathrm{b}} \\
0.0031\end{array}$ \\
\hline
\end{tabular}

$a, b$ Means in the same row with different superscripts are significantly different $(P<0.05)$.

+ Constants in the model: $p=a+b\left(1-\mathrm{e}^{-c t}\right)$. 